\title{
Qualitative Histology and Quantitative Bacteriology in Various Tissues of 50 Leprosy Patients*
}

\author{
NOSHIR H. ANTIA \\ Tata Department of Plastic Surgery, J. J. Hospital, Bombay-8, India \\ and \\ NARENDRA J. PANDYA \\ Nair Hospital and Jaslok Hospital and Research Centre, Bombay, India
}

\begin{abstract}
Fifty patients, 45 males and 5 females, from different parts of the leprosy spectrum and at various stages of the disease and its treatment, were examined both by multiple skin smears, nasal scrapings and also by qualitative histology and quantitative bacteriology of skin, dartos, lymph node, nasal mucosa, muscle and nerve. A total of 797 tissues were studied by histology as well as homogenization.

Our study revealed that the qualitative involvement and quantitative bacillary load in the nerves was highest of all the tissues examined. A high incidence of $M$. leprae in the nerves of tuberculoid patients $(40 \%)$ as opposed to other tissues-skin $(7 \%)$, dartos $(8 \%)$, nasal mucosa $(7 \%)$, ly mph node $(7 \%)$, voluntary muscle $(0 \%)$ was also observed. The nerve was also found to be a major and the most important reservoir of $M$. leprae. Scrotal skin biopsy was shown to be a suitable and practical site for diagnosis of leprosy. A smear obtained from the homogenate of the scrotal skin can be a useful investigation when histological facilities are not available. The findings of histology and homogenization correlate fairly well except in the skin where homogenization $(24 \%)$ was better than histology (18\%) for detection of bacilli. Nasal mucosa had a similar bacillary load while the lymph node showed a higher load. The importance of voluntary or involuntary muscle (dartos) as a reservoir of $M$. leprae was not borne out in our study.
\end{abstract}

\section{Introduction}

Mycobacterium leprae was first demonstrated by Hansen in 1873. Since then the presence of $M$. leprae has been associated with leprosy infection in man even though the organism has not yet been cultured in vitro. Shepard (1960) demonstrated a limited growth of $M$. leprae in the footpad of normal mice and

This work was undertaken in the Research Laboratory of the TATA Department of Plastic Surgery, Bombay-8.

Received for publication 22nd January, 1976. 
Rees and Weddell (1970) have described lesions in the tissues of mouse resembling those of man.

Though lesions in nerves and other tissues have been known since the earliest writings on this disease (Danielssen and Boeck, 1848), it is the external visible cutaneous lesions which have held the interest of leprologists. The present method of declaring a patient infectious or non-infectious is based on smears from the skin and the nasal mucosa. Histological examination when performed for diagnostic purposes is almost invariably of the skin. Khanolkar (1951, 1955), Dastur (1955), Lumsden (1964) and Antia et al. (1970) have described the presence of M. leprae in Schwann cells of peripheral nerves. Pearson et al. (1970) have demonstrated the organism in the striated muscle of mice and man and state that the Morphological Index is higher in muscle than in skin. Job et al. (1969), as well as Harman (1968), demonstrated $M$. leprue in the non-striated muscle of the scrotum. The organisms have been described in the lymph nodes (Turk and Walters, 1968), testes, liver, spleen, bone marrow and even in the brain and cerebrospinal fluid (Vaidya et al., 1970). Almost all tissues are invaded in lepromatous leprosy.

Most of these findings are of a qualitative nature though Pearson has described quantitative findings in human muscle and skin.

This study was undertaken to establish quantitatively the load of M. leprae in various tissues. Unlike many others, this was not a post-mortem study, nor was it restricted to the lepromatous side of the spectrum. It involved patients from different parts of the spectrum and at various stages of the disease and its treatment. It was hoped that the study may help to a better understanding of tissue invasion in leprosy and identify tissues which are a repository of M. leprae.

\section{Materials and Methods}

The nature of this investigation was explained to patients undergoing reconstructive surgery in the Tata Department of Plastic Surgery. Forty-five male and 5 female subjects volunteered to offer tissue biopsies. A detailed history and physical signs were recorded in each case including the duration of the disease and regularity or otherwise of treatment. The Lepromin Test was performed using Mitsuda antigen and read at 21 days. Skin smears by the slit and scrape method were taken from the ear, forehead, cheek, buttock, a skin patch and also from the nasal mucosa, and examined for acid fast bacilli after Ziehl Neelsen staining.

\section{BIOPSIES}

The following biopsies were obtained under general anaesthesia.

1. Skin: an elliptical biopsy from the margin of one or more of the most recent and active lesions penetrating to deep fascia, in all 50 cases. 80 skin biopsies were obtained.

2. Nasal mucosa: a small mucosal biopsy of an average weight of $40 \mathrm{mg}$ was obtained from one surface of the septum in 47 cases. The underlying cartilage was included in some cases.

3. Dartos: scrotal skin and underlying dartos muscle biopsy was performed in all 45 male patients.

4. Muscle: 84 biopsies were taken from paralysed as well as unparalysed muscles including flexor digitorum sublimis, tibialis posterior, tibialis anterior, flexor carpi ulnaris, first dorsal interosseous, triceps, platysma, etc. 
5. Lymph node: of the total 56 lymph nodes biopsied, there were 34 axillary, 15 inguina, 6 supratrochlear and 1 cervical region. Multiple biopsies were obtained in 5 cases.

6. Nerve: this varied from a bundle biopsy of as little as $16 \mathrm{mg}$ in cases where the nerve was not paralysed to total excision biopsy of a segment of the nerve, weighing $465 \mathrm{mg}$ in a totally paralysed nerve. The total 107 biopsies included: the ulnar nerve in the arm 28 , ulnar nerve in the forearm 16 , median nerve 4 , radial cutaneous nerve 18, index branch of radial cutaneous nerve 21 , lateral popliteal 10 , posterior tibial 1 , dorsal branch of ulnar 4 , sural 1 , digital 1 , greater auricular 2, anterior cutaneous of the leg 1. Multiple nerve biopsies were obtained in 35 cases, the ulnar nerve being biopsied simultaneously above the elbow and in the lower forearm in 18 cases.

7. Bone Marrow: this was obtained by sternal puncture after incising the skin in 40 cases.

Method: the instruments were cleaned with spirit between biopsies. Each biopsy was divided approximately into two halves for light microscopy and homogenization. (The weights quoted are only for the tissues which were weighed for homogenization.) The average weight of the tissue for homogenization varied generally between 100 to $400 \mathrm{mg}$. Formol Zenker was used as a fixative and $5 \mu \mathrm{m}$ thick sections were stained with TRIFF and Fite Faraco stains. In cases where the biopsied tissue was minute as in the index branch of radial cutaneous nerve or bundle biopsy of a nerve, it was subjected only to light microscopy. All nerve tissues were also stained by the Holmes Silver Technique of $15 \mu \mathrm{m}$ sections. Suitable biopsies of nerves were also fixed for electronmicroscopy.

A manual glass homogenizer was employed. The tissue was weighed on a Mettler balance accurate to 4 decimals. $0.1 \%$ bovine albumin in distilled water was used as diluent in a rough proportion of $1 \mathrm{ml}$ diluent for $200 \mathrm{mg}$ of tissue.

Bacillary count was done as per the method of Rees (1964). A standardized platinum loop with a volume of $0.004 \mathrm{ml}$ was used for producing 4 spots on a glass slide (each of $8 \mathrm{~mm}$ diameter). The slides were fixed by inverting them over a beaker of formalin for $5 \mathrm{~min}$ and then over a steam bath for $3 \mathrm{~min}$. They were stained by the "cold method" using $2 \%$ carbol fuchsin for $20 \mathrm{~min}$. The bacilli were counted under a flat field objective of $\times 100$ magnification. Thirty-two microscopic fields were counted per slide, but if they showed no bacilli, 100 fields were counted to exclude the presence of any bacilli. The Morphological Index of bacilli for each tissue was also noted. In tissues showing the presence of acid fast bacilli, the homogenate was streaked on Lowenstein Jansen medium and $0.03 \mathrm{ml}$ of it was injected into each hind footpad of 10 Swiss white mice without dilution. The histological sections were scanned for the presence of $M$. leprae and for the nature of the cells harbouring them. The disease was also classified histologically. The TRIFF stain and histology were done independently in Bombay and by $\mathrm{Dr}$ D. J. Harman at the Leprosy StudyCentre in London.

\section{Results}

Fifty cases were studied comprising 45 males and 5 females; age varied from 11 to 51 years. The duration of the disease varied from 11 months to 31 years and the treatment varied from 0 to 30 years. The classification as per the Ridley-Jopling Scale using both clinical and histological criteria and their relation 
TABLE 1

Type of leprosy and duration of chemotherapy

\begin{tabular}{|c|c|c|c|c|}
\hline \multirow{2}{*}{$\begin{array}{l}\text { Type } \\
\text { (after Ridley-Jopling) }\end{array}$} & \multicolumn{3}{|c|}{ Period of chemotherapy } & \multirow[b]{2}{*}{ Total } \\
\hline & Intreated & $0-4$ years & 5 years and over & \\
\hline $\begin{array}{l}\text { Tuberculoid } \\
\text { TT-BT }\end{array}$ & 3 & 16 & 4 & 23 \\
\hline $\begin{array}{l}\text { Borderline } \\
\text { BB-BL }\end{array}$ & 1 & 10 & 3 & 14 \\
\hline $\begin{array}{l}\text { Lepromatous } \\
\text { LL }\end{array}$ & 2 & 2 & 9 & 13 \\
\hline Total & 6. & 28 & 16 & 50 \\
\hline
\end{tabular}

to treatment is given in Table 1. The duration and regularity of treatment is plotted in Fig. 1.

Table 2 summarises the findings of routine smears and the bacteriological positivity of various tissues per patient and per number of specimens, and includes actual counts $/ \mathrm{g}$ of tissue.

The diagnostic reliability of homogenization vs. histology was evaluated for each tissue by finding out how of ten one method gave a positive result when the other had failed.

Applying McNemar's Test to these data shows homogenization to be superior to histology $(P<0.05)$ at least in so far as skin was concerned (Table 3$)$.

The bacteriological positivity of tissues correlated to the classification is shown in Fig. 2. The tuberculoid nerves showed a high percentage of positive results (6 of 15 or $40 \%$ ), as opposed to other tissues, which gave a very low percentage of positive results ( 0 to $8 \%)$. The difference between nerves and any of the other tissues except the muscle, was not significant $(P>0.05)$ when examined by Fischer's exact test.

Analysis of variance showed that the difference among the tissue averages was

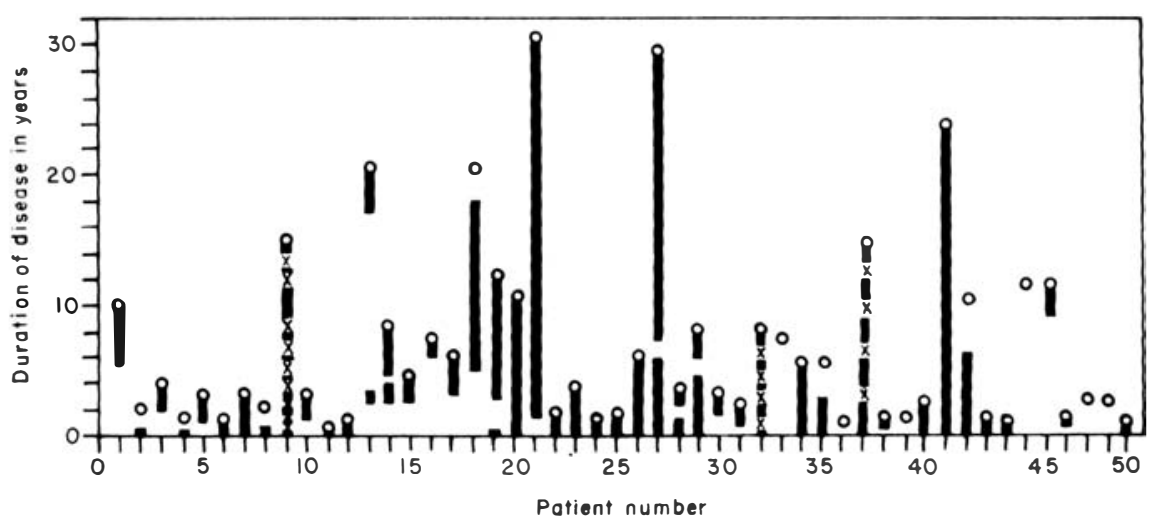

Fig. 1. Duration and regularity of treatment. (O) Earliest symptom; (-) regualr treatment; $(-x-)$ irregular treatment. 
TABLE 2

Bacteriological positivity of tissues per patient and per number of specimens

\begin{tabular}{|c|c|c|c|c|c|c|c|c|}
\hline Tissue & $\begin{array}{l}\text { No. of } \\
\text { patients }\end{array}$ & $\begin{array}{l}\text { Smears } \\
\%+\text { ve }\end{array}$ & $\begin{array}{c}\text { Histology } \\
\%+\text { ve }\end{array}$ & $\begin{array}{c}\text { No. of } \\
\text { biopsies }\end{array}$ & $\begin{array}{c}\text { Histology } \\
\%+\text { ve }\end{array}$ & $\begin{array}{c}\text { No. of } \\
\text { homogenates }\end{array}$ & $\%+v e$ & $\begin{array}{l}\text { Bacterial count } \\
\left(\times 10^{6}\right)\end{array}$ \\
\hline Nerve & 49 & & 60 & 107 & 43 & 79 & 41 & $34 \pm 10.6$ \\
\hline Dartos & 40 & & 34 & 45 & 34 & 40 & 33 & $5.0 \pm 10.7$ \\
\hline Lymph node & 48 & & 22 & 56 & 25 & 54 & 25 & $10.7 \pm 9.2$ \\
\hline Nose (biopsy) & 41 & & 22 & 47 & 22 & 41 & 20 & $0.65 \pm 10.6$ \\
\hline Nose (smear) & 48 & 14 & & & & & & \\
\hline Skin (biopsy) & 50 & & 18 & 80 & 15 & 80 & 21 & $1.4 \pm 7.6$ \\
\hline 1 or 2 smears & 48 & 12 & & & & & & \\
\hline multiple smears & 48 & 18 & & & & & & \\
\hline Muscle & 50 & & 6 & 84 & 3.5 & 84 & 6 & $0.17 \pm 7.4$ \\
\hline \multirow[t]{2}{*}{ Bone marrow } & 40 & 0 & & & & & & \\
\hline & & & & tal 419 & & Total 378 & & \\
\hline
\end{tabular}

Total tissues studied $=797$. 


\section{TABI.I 3}

Diagnostic reliability of homogenization and histology by tissues

\begin{tabular}{lcccc}
\hline Tissue & $\begin{array}{c}\text { No. + ve by } \\
\text { homo only }\end{array}$ & $\begin{array}{c}\text { No. + ve by } \\
\text { histo only }\end{array}$ & $\mathrm{x}^{2}{ }^{*}$ & $\begin{array}{c}\text { Significant } \\
\text { lifferencet }\end{array}$ \\
\hline Skin & 5 & 0 & 5 & $\mathrm{~S}$ \\
Dartos & 1 & 3 & 1 & $\mathrm{NS}$ \\
Nerve & 2 & 8 & 3.6 & $\mathrm{NS}$ \\
Nasal mucosa & 0 & 0 & 0 & NS \\
Lymph node & 1 & 2 & 0.33 & NS \\
Muscle & 2 & 1 & 0.33 & NS \\
\hline
\end{tabular}

* Calculated hy McNemar's Test (without Yates’ correction

+ Level of significance $P \leqslant 0.05$.

$\$$ Feinstein, A. R. (1973). Clinical Pharmacology and Therapeutics 14, 898.

\begin{tabular}{|c|c|c|}
\hline Skin & $\frac{T T-B T}{L L L} B B-B L$ & $12 / 50$ \\
\hline Dartos & 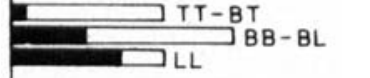 & $16 / 45$ \\
\hline Nerve & 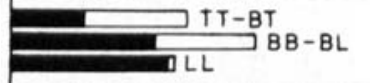 & $31 / 50$ \\
\hline Nosal mucoso & 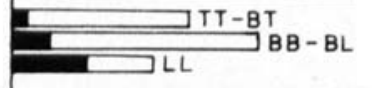 & $10 / 48$ \\
\hline Lymph node & $\begin{array}{l}T T-B T \\
L L\end{array}$ & $13 / 49$ \\
\hline Muscle & $\begin{array}{l}\square T T-B T \\
L L\end{array}$ & $15 / 50$ \\
\hline$T$ issue & $\begin{array}{lllllll} & 5 & 10 & 15 & 20 & 25\end{array}$ & \\
\hline
\end{tabular}

Bocteriologically + VE and clossification

significant $\left(\mathrm{F}_{5}, 372=2.8 ; P<0.05\right)$. Subsequently, since the number of observations in each group was not the same, a "standard error of difference" was calculated separately for each of the 15 individual differences, and their significance tested by employing the Student's $t$-test. The average load of $M$. leprae in nerve was found to be significantly higher $(P<0.05)$ than that in skin, dartos, nasal mucosa and muscle, but not in lymph node.

\section{HISTOLOGY}

The salient findings will be described tissuewise.

Skin: this showed the classical changes as described by most authors.

Dartos: there were marked histological changes in the region of the neurovascular bundles, i.e. Schwannian proliferation, macrophage and lympho- 
cytic infiltration. The bacilli seen were almost always restricted to these areas. The smooth muscle of the dartos was rarely infiltrated and showed the presence of bacilli in only 4 cases.

Lymph node: the increase in germinal centres and replacement of the gland by macrophage infiltration in advanced lepromatous leprosy was noted. The bacilli were chietly in the macrophages, rarely in the dendritic cells of the germinal follicles.

Nasal mucosa: there was loss of cilia and stratification of epithelium in the majority of cases, even in the early ones. This was also observed on naked eye examination of the septum as a process of "creeping epithelialization".

Voluntary muscle: infiltration and presence of bacilli was chiefly in the intramuscular nerves and in the interstitial tissue between nuscle fibres. Actual infiltration of muscle (leprous myositis) was seen only in 3 cases.

Nerves: these showed by far the most advanced histological evidence of disease out of all the tissues examined in any individual patient. Early cases showed Schwann cell proliferation. Bacilli were seen both in the Schwann cells and in macrophages. They were generally better preserved in the Schwann cells while those in macrophages were usually granular.

\section{Conclusions}

The following conclusions can be drawn from the findings of this study.

In the cases studied, the routine slit and scrape method of diagnosis of leprosy by a single patch and/or ear lobule as is used in the field, provided only $12 \%$ positive results, while nerve biopsies revealed $60 \%$ positivity. Multiple skin smears increased the positivity only to $18 \%$ while nasal scrapings yielded a $14 \%$ positive result. Nasal biopsy increased this to $20 \%$.

As expected, the bacillary load of tissue was lowest in the tuberculoid part of the spectrum and greatest on the lepromatous side.

The findings of histology and homogenization correlate fairly well except in the skin where homogenization (24\%) was better than histology (18\%) for detection of bacilli. Since this difference was significant (Table 3), which tallies with our clinical impression, homogenization of the skin patch may be used where facilities for histology are not available.

Multiple skin patch biopsies should be carried out whenever possible as they have a better chance of providing a positive result.

The importance of voluntary muscle as a reservoir of $M$. leprae, as described by other authors, has not been borne out in this study. In fact, this study revealed that muscle was the least affected tissue in man. Actual myositis was even rarer than interstitial tissue involvement.

Scrotal skin biopsy has been shown to be a most suitable and practical site for the diagnosis of leprosy both by histological and bacteriological findings. This involvement is chiefly restricted the the nerves. In fact, clinically uninvolved scrotal biopsy is often a better indicator of leprosy than even a clinically involved skin patch in the borderline and lepromatous types. (Pandya and Antia, 1974). Wherever histology facilities are not available, the presence of acid fast bacilli can be ascertained by the examination of a smear obtained from the homogenate. This would prove to be a superior method of bacteriological diagnosis to multiple skin smears or nasal scrapings or even homogenization of skin patch especially in 
lepromatous leprosy and could be particularly useful in field studies in the developing countries.

Lymph nodes showed a high rate of bacillary presence. This may indicate that a large number of bacilli are trapped in the lymph nodes for eventual destruction. Analysis showed that it did not seem to matter which lymph nodes were examined in any given case.

Nasal mucosa had a smaller bacillary load. This small load may be due to increased destruction in the carlier phases of treatment.

The same reasons may account for the absence of acid fast bacilli from all the bone marrow smears examined. There was no untreated lepromatous case in this series.

The qualitative involvement and quantitative bacillary load in the nerves was found to be highest of all the tissues examined. Nerve biopsy has been shown to be a feasible procedure and provides the best histological and bacteriological evidence for the diagnosis of leprosy. Selection of one of the clinically most involved nerves gives as good a result as multiple nerve biopsies. It may not at present be a practical method of diagnosis except in special circumstances when diagnosis is in doubt. The index branch of the radial cutaneous nerve or a bundle biopsy of an involved nerve is helpful for diagnosis in early leprosy.

The high incidence of $M$. leprae in the nerves of patients declared negative by the routine skin and nasal scrapings method is disturbing and may emphasize the need for prolonged treatment. It may also account for the high relapse rate even af ter bacteriological negativity has been demonstrated.

The failure to reach statistical significance in spite of showing a high percentage of positive results in the tuberculoid nerves is very probably due to the small size of the samples. However, the size of the difference suggests that it is clinically important and cannot be ignored.

The high incidence of $M$. leprae in the nerves of tuberculoid patients $(40 \%)$ as opposed to other tissues (skin $(7 \%)$, dartos $(8 \%)$, nasal mucosa $(7 \%)$, lumph node $(7 \%)$, voluntary muscle $(0 \%)$ ) may indicate the reason for the high incidence of the nerve involvement so typical of this type of disease.

Our study showed the nerve as a major and most important reservoir of $M$. leprae in man both on qualitative histology and quantitative bacteriology. The bacilli in the nerves were more solid staining when compared with the same in other tissues of the same patient. The bacterial load was highest in the nerves when compared with other tissues in the same patient. Inoculation in the mouse footpad also showed consistently higher growth curves from the nerves when compared with other tissues in the same patient (Bhatt and Antia, 1974). The examination of the index branch of the radial cutaneous nerve has shown that this nerve is the earliest tissue involved even prior to any clinical manifestations (Antia et al., 1974). This leads us to believe that leprosy results in a diffuse though sub-clinical peripheral neuropathy even at the earliest stages of the disease.

\section{ACKNOWLEDGEMENTS}

This study was undertaken with a grant from The Wellcome Trust, London.

We wish to thank Dr D. J. Harman of the Leprosy Study Centre, London, for reviewing the histology, Dr A. S. Nanivadekar. M.D., Medical Director, Pfizer Ltd. for help in statistical analysis of resultz and Dr (Mrs) S. Bhasin and Miss P. V. Bhatt for technical assistance. 


\section{References}

Antia, N. H., Mehta, Lata, Shetty, Vanaja and Irani, P. F. (1975). ('linical, electrophysiological, quantitative histological and ultrastructural studies of the index branch of radial cutaneous nerve in leprosy. Int. J. Lepr.43, 256-264.

Antia, N. H., Pandya, S. S. and Dastur, I). K. (1970). Nerves in the arm in leprosy. I. Clinical, electrodiagnostic and operative aspects. Int. J. Leprosy 38, 12.

Bhatt, P. V. and Antia, N. H. (1974). Study of viability of M. leprae from multiple tissue biopsies of ten leprosy patients using the mouse foot pad technique. Lepr. India 46, 1.

Danielssen, D. C. and Boeck, W. (1848). Traite de las spedasletied ou elephantiasis des grecs. (Trans L. A. Casson). Paris: J. B. Bailliere.

Dastur, D. K. (1955). Cutaneous nerves in leprosy. The relationship between histopathology and cutaneous sensibility. Brain 78, 615 .

Harman, D. J. (1968). Myobacterium leprae in muscles. Lepr. Rev. 39, 197.

Job, (. K., Karat, A. B. A., Karat, S. and Mathan, M. (1969). Leprous myosit is-an histopathological and electron microscopic study. Lepr. Rev. 40, 9.

Khanolkar, V. R. (1951). Studies in the histology of early lesions in leprosy. Indian ('ouncil of Medical Research. Special Report Series No. 19.

Khanolkar, V. R. (1955). Perspectives in pathology of leprosy. Indian J. Med. 9, (Suppl 1 ).

Lumsden, C. E. (1964). Leprosy and the Schwann cell in vivo and in vitro. Leprosy in theory and Practice, 2nd ed. (Eds R. (i. Cochrane and T. F. Davey). p. 221. Bristol: John Wright \& Sons Ltd.

Pandya, N. J. and Antia, N. H. (1974). The value of scrotal biopsy in leprosy. Lepr. Rev. 45, 145.

Pearson, J. M. H., Rees, R. J. W., Weddell, A. (i. H. (1970). M. leprae in striated muscle of patients with leprosy. Lepr. Rev. 41, 155.

Rees, R. J. W. (1964). Limited multiplication of acid fast bacilli in the footpads of inice inoculated with Mycobacterium leprae. Br. J. exp. Path. 45, 207.

Rees, R. J. W. and Weddell, A. G. M. (1970). Transmission of human leprosy to the mouse and its clinical implications. Trans. R. Soc. trop. Med. Hyg. 64, 31.

Shepard, C. C. (1960). The experimental diseases that follow the infection of human leprosy bacilli into footpads of mice. J. exp. Med. 112, 34 .

Turk, J. L. and Walters, M. F. R. (1968). Immunological basis of depression of cellular immunity and the delayed allergic response in patients with lepromatous leprosy. Lancet 2,436 .

Vaidya, M. C., Palmer, F., Weddell, (j. and Rees, R. J. W. (1970). A note of the presence of Mycobacterium leprae in the central nervous system of a mouse with lepromatous leprosy. Med. Microbiol. 3, 194. 